\title{
Raman and infrared spectroscopic studies of phurcalite from Red Canyon, Utah, USA - Implications for the molecular structure
}

\author{
Jiří Čejka ${ }^{\mathrm{a}, \mathrm{b}}$, Jiří Sejkora ${ }^{\mathrm{a}}$, Ricardo Scholz ${ }^{\mathrm{b}}$, Andrés López ${ }^{\mathrm{c}}$, Yunfei Xi ${ }^{\mathrm{c}}$, Ray L. Frost ${ }^{\mathrm{c}, *}$ \\ ${ }^{a}$ Department of Mineralogy and Petrology, National Museum, Cirkusová 1740, CZ-193 00, Praha 9, Czech Republic \\ ${ }^{\mathrm{b}}$ Geology Department, School of Mines, Federal University of Ouro Preto, Campus Morro do Cruzeiro, Ouro Preto, MG 35, 400-00, Brazil

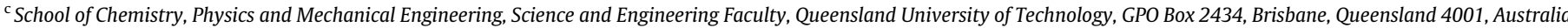

\section{H I G H L I G H T S}

- Raman and infrared spectra of the uranyl mineral phurcalite

$\mathrm{Ca}_{2}\left(\mathrm{UO}_{2}\right)_{3} \mathrm{O}_{2}\left(\mathrm{PO}_{4}\right)_{2} \cdot 7 \mathrm{H}_{2} \mathrm{O}$.

- From Red Canyon, Utah, USA.

- Observed bands were assigned to the stretching and bending vibrations of $\left(\mathrm{UO}_{2}\right)^{2+}$ and $\left(\mathrm{PO}_{4}\right)^{3-}$ units.

- Hydrogen bond lengths were inferred from observed stretching vibrations.

- Structurally nonequivalent $\mathrm{U}^{6+}$ and $\mathrm{P}^{5+}$ was inferred from the number of corresponding stretching bands.

\section{A R T I C L E I N F O}

\section{Article history:}

Received 23 January 2014

Received in revised form 18 March 2014

Accepted 19 March 2014

Available online 26 March 2014

\section{Keywords:}

Phurcalite

Mineral

Raman and infrared spectroscopy

$\mathrm{U}-\mathrm{O}$ bond length

Hydrogen bond lengths

\section{G R A P H I C A L A B S T R A C T}

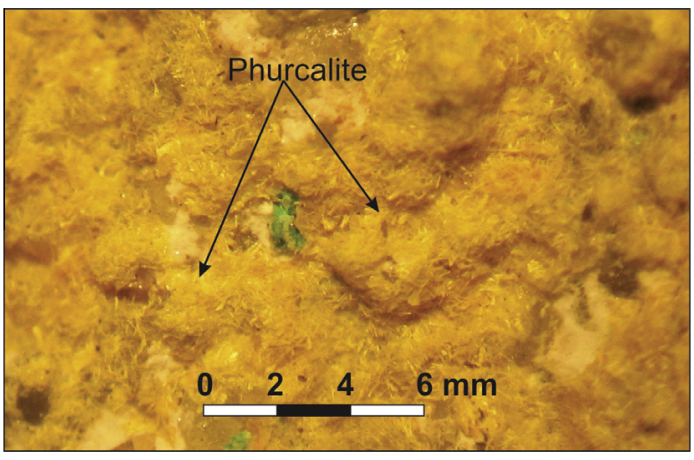

\section{A B S T R A C T}

Raman and infrared spectra of the uranyl mineral phurcalite, $\mathrm{Ca}_{2}\left(\mathrm{UO}_{2}\right)_{3} \mathrm{O}_{2}\left(\mathrm{PO}_{4}\right)_{2} \cdot 7 \mathrm{H}_{2} \mathrm{O}$, from Red Canyon, Utah, USA, were studied and tentatively interpreted. Observed bands were assigned to the stretching and bending vibrations of $\left(\mathrm{UO}_{2}\right)^{2+}$ and $\left(\mathrm{PO}_{4}\right)^{3-}$ units and to the stretching and bending vibrations and libration modes of water molecules. Approximate lengths of $\mathrm{U}-\mathrm{O}$ in $\left(\mathrm{UO}_{2}\right)^{2+}$ and $\mathrm{O}-\mathrm{H} \cdots \mathrm{O}$ hydrogen bond lengths were inferred from observed stretching vibrations. The presence of structurally nonequivalent $\mathrm{U}^{6+}$ and $\mathrm{P}^{5+}$ was inferred from the number of corresponding stretching bands of $\left(\mathrm{UO}_{2}\right)^{2+}$ and $\left(\mathrm{PO}_{4}\right)^{3-}$ units observed in the Raman and infrared spectra.

(c) 2014 Elsevier B.V. All rights reserved.

\section{Introduction}

Uranium as a litophil element is characterised by strong affinity to oxygen, that neither an element, nor mineral sulphides, arsenides or halogenides have been found and all natural uranium compounds contain oxygen. The most important valences (oxidation numbers) under natural conditions are $\mathrm{U}^{4+}$ and $\mathrm{U}^{6+}$.

\footnotetext{
* Corresponding author. Tel.: +61 73864 2407; fax: +61 738641804 .

E-mail address: r.frost@qut.edu.au (R.L. Frost).
}

$\mathrm{U}^{6+}$ forms the stable uranyl, $\left(\mathrm{UO}_{2}\right)^{2+}$, ion. Uranyl ions participate in formation of uranyl minerals, such as uranyl oxide hydrates and uranates, silicates, phosphates, arsenates, vanadates, molybdates, sulphates, carbonates, selenites, tellurites and wolframates. Uranyl minerals are classified on the basis of their anions e.g. [1] or uranyl anion topology e.g. [2]. Some uranyl phosphates, uranyl arsenates, uranyl selenites, uranyl sulphates and uranyl carbonates contain sheets based upon anion topologies with triangles, squares, pentagons and hexagons [2,3]. The phosphuranylite sheet anion topology contains pentagons that share edges, resulting in dimers, 
which are in turn linked into chains by sharing edges with hexagons. These chains are linked through chains of edge sharing triangles and squares, arranged such that the triangles and squares alternate along the chain (for details see especially [2,3], and may be also e.g. [4,5]). According to Locock [6], the minerals of the phosphuranylite group are hydrated phosphates and arsenates, with the general formula $\mathrm{A}_{k}^{+}\left[\left(\mathrm{UO}_{2}\right)_{3}\left(\mathrm{XO}_{4}\right)_{2} \Phi_{2}\right] \cdot n \mathrm{H}_{2} \mathrm{O}$, where $\mathrm{A}=$ monovalent, divalent, trivalent, or tetravalent cations (or complex cations), $\mathrm{X}=\mathrm{P}^{5+}$, or $\mathrm{As}^{5+}$, and $\Phi=\mathrm{O}^{2-}$ or $(\mathrm{OH})^{-}$. These minerals are defined by the presence of the phosphuranylite type sheet, which contains uranyl pentagonal and hexagonal bipyramids as coordination polyhedra, which share edges to form chains, and in turn are cross-linked by sharing vertices and edges with phosphates or arsenates tetrahedra. The interlayer region generally contains cations and water molecules, and the sheets are usually linked by hydrogen bonding and through bonds from the interlayer cations to oxygen atoms of the sheets. In some cases, sheets in minerals of the phosphuranylite group are linked by bonds to polyhedra of $\mathrm{U}^{6+}$ in the interlayer, resulting in framework structures [6].

Phurcalite was first described at Bergen an der Trieb, Saxony, Germany by Deliens and Piret [7] as $\mathrm{Ca}_{2}\left(\mathrm{UO}_{2}\right)_{3}\left(\mathrm{PO}_{4}\right)_{2}(\mathrm{OH})_{4} \cdot 4 \mathrm{H}_{2} \mathrm{O}$. Piret and Declerq determined crystal structure of phurcalite [8]. Phurcalite was also described at some other localities [9-19]. Redetermination of the crystal structure of phurcalite was carried out by Silva [20], Atencio [21] and Atencio et al. [15]. On this basis, chemical formula of phurcalite $\mathrm{Ca}_{2}\left(\mathrm{UO}_{2}\right)_{3} \mathrm{O}_{2}\left(\mathrm{PO}_{4}\right)_{2} \cdot 7 \mathrm{H}_{2} \mathrm{O}$ was inferred. Infrared spectrum of phurcalite was published and partly interpreted by Camargo [9], Braithwaite et al. [18], and Atencio et al. [15]. Raman spectra of two phurcalite samples are available in the RRUFF data base, however, as usually, without any interpretation. Infrared and Raman spectra of phurcalite were presented also by Frost et al. [22].

Phurcalite, $\mathrm{Ca}_{2}\left(\mathrm{UO}_{2}\right)_{3} \mathrm{O}_{2}\left(\mathrm{PO}_{4}\right)_{2} \cdot 7 \mathrm{H}_{2} \mathrm{O}$, is orthorhombic, space group $\mathrm{Pbca}=D_{2 h}^{15}$. The crystal structure of phurcalite consists of $\left[\left(\mathrm{UO}_{2}\right)_{3} \mathrm{O}_{2}\left(\mathrm{PO}_{4}\right)_{2}\right]^{4 n-}{ }_{n}$, which are connected by $\mathrm{Ca}^{2+}$ cations and seven water molecules. In the crystal structure, there are three symmetrically (structurally) distinct (nonequivalent) $\mathrm{U}^{6+}$ coordination polyhedra, one hexaxonal bipyramid and two pentagonal bipyramids, two symmetrically different $\mathrm{Ca}^{2+}$ cations, one capped trigonal prism and one triangulated dodecahedron, and two structurally nonequivalent $\mathrm{P}^{5+}$ tetrahedra. Intersheet linkage is increased through hydrogen bonding from the water molecules to oxygen anions of the sheets [15].

\section{Experimental}

Mineral

The phurcalite sample studied in this work forms part of the collection of the Geology Department of the Federal University of Ouro Preto, Minas Gerais, Brazil, with sample code SAC-136. The phurcalite sample originated from the Posey Mine, Red Canyon, White Canyon District, San Juan Co., Utah, USA. Carefull handpicked sample was used for X-ray powder diffraction experiment. To minimize the complicated shape of background, the samples studied were placed on a flat low-background silicon wafer. Powder XRD measurements were carried out with $\mathrm{CuK} \alpha$ radiation at a Bruker D8 Advance diffractometer $(40 \mathrm{kV}, 40 \mathrm{~mA})$ in the range $4-60^{\circ} 2 \theta$ in the step-scan mode $0.01 / 20 \mathrm{~s}$. First, the mineral was semi-quantitatively analysed by EDS methods for chemical composition. Later, phurcalite was quantitatively analysed by Cameca SX 100 electron microprobe system in wavelength dispersion mode. Studied sample was mounted into the epoxide resin and polished. The polished surface was coated with carbon layer $250 \AA$. An acceleration voltage of $15 \mathrm{kV}$, a specimen current of $10 \mathrm{nA}$, and a beam diameter of $5 \mu \mathrm{m}$ were used. Well-defined natural and synthetic compounds were used as standards. The raw intensities were converted to the concentrations using automatic PAP matrix correction software package.

\section{Raman spectroscopy}

The crystals of phurcalite were placed on the stage of an Olympus BHSM microscope, equipped with $10 \times$ and $50 \times$ objectives and part of a Renishaw 1000 Raman microscope system, which also includes a monochromator, a filter system and a Charge Coupled Device (CCD). Raman spectra were excited by a HeNe laser $(633 \mathrm{~nm})$ at a resolution of $2 \mathrm{~cm}^{-1}$ in the range between 100 and $4000 \mathrm{~cm}^{-1}$. Repeated acquisition using the highest magnification was accumulated to improve the signal to noise ratio. Spectra were calibrated using the $520.5 \mathrm{~cm}^{-1}$ line of a silicon wafer. In order to ensure that the correct spectra are obtained, the incident excitation radiation was scrambled. Previous studies by the authors provide more details of the experimental technique. Spectra at liquid nitrogen temperature were obtained using a Linkam thermal stage (Scientific Instruments Ltd., Waterfield, Surrey, England).

\section{Infrared spectroscopy}

Infrared spectra were obtained using a Nicolet Nexus 870 FTIR spectrometer with a smart endurance single bounce diamond ATR cell. Spectra over the $4000-525 \mathrm{~cm}^{-1}$ range were obtained by the co-addition of 64 scans with a resolution of $4 \mathrm{~cm}^{-1}$ and a mirror velocity of $0.6329 \mathrm{~cm} / \mathrm{s}$. Spectral manipulation such as baseline adjustment, smoothing and normalisation was performed using the GRAMS ${ }^{\circledR}$ software package (Galactic Industries Corporation, Salem, NH, USA).

Spectroscopic manipulation such as baseline adjustment, smoothing and normalisation were performed using the Spectracalc software package GRAMS (Galactic Industries Corporation, $\mathrm{NH}, \mathrm{USA}$ ). Band component analysis was undertaken using the Jandel 'Peakfit' software package, which enabled the type of fitting, function to be selected and allows specific parameters to be fixed or varied accordingly. Band fitting was done using a Gauss-Lorentz cross-product function with the minimum number of component bands used for the fitting process. The Gauss-Lorentz ratio was maintained at values greater than 0.7 and fitting was undertaken until reproducible results were obtained with squared correlations of $r^{2}$ greater than 0.995 .

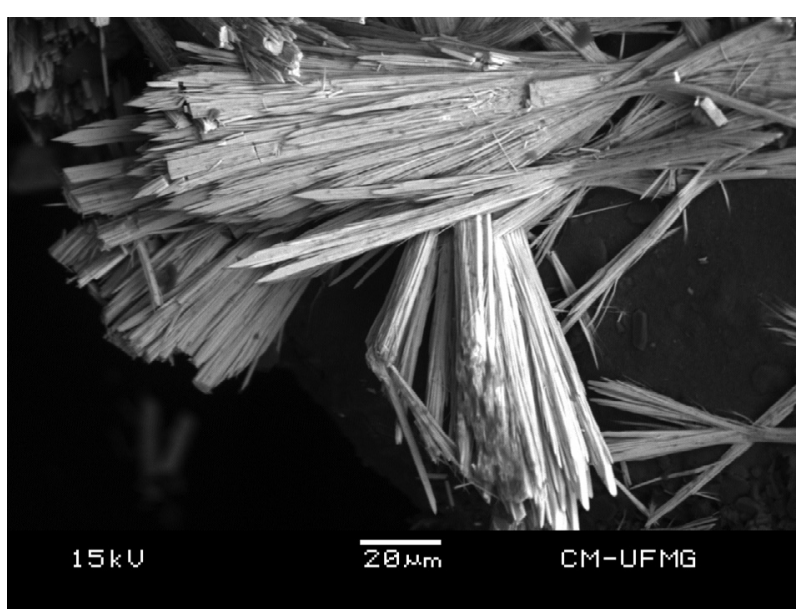

Fig. 1. Backscattered electron image (BSI) of a phurcalite crystal aggregate up to $0.2 \mathrm{~mm}$ in length. 


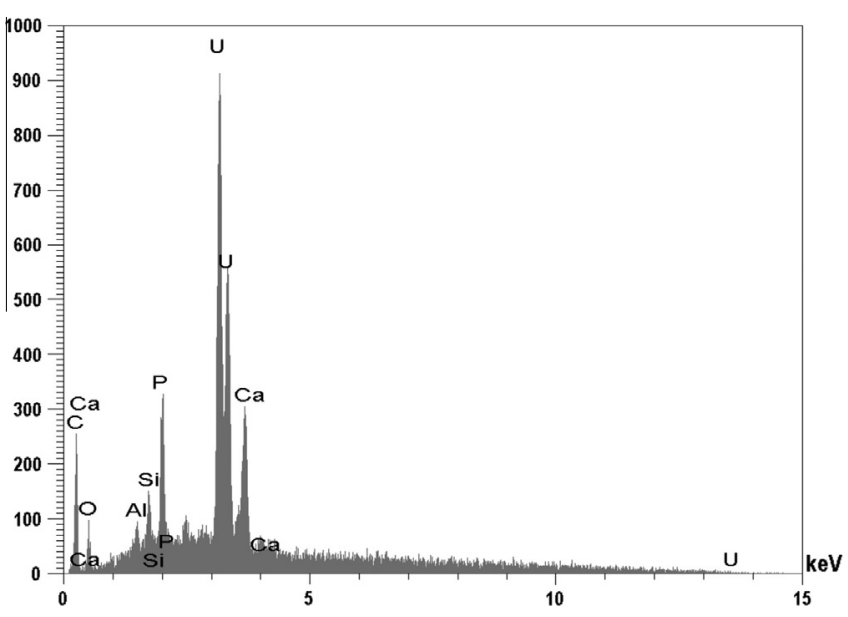

Fig. 2. EDS analysis of phurcalite.

\section{Results and discussion}

\section{Characterization of studied sample}

The BSI image of phurcalite sample studied in this work is shown in Fig. 1. The image shows a $200 \mu \mathrm{m}$ aggregate of needlelike crystals. The unit-cell parameters of phurcalite refined from measured powder XRD: $a$ 17.391(1), $b$ 15.984(1), c 13.561(2) Å, $V$ $3769.8(6) \AA^{3}, Z 8$, agree very well with published data [15]. A semi-quantitative EDS analysis shows calcium uranyl phosphate with minor amounts of $\mathrm{Si}$ and $\mathrm{Al}$ (Fig. 2). The results of EPMA study
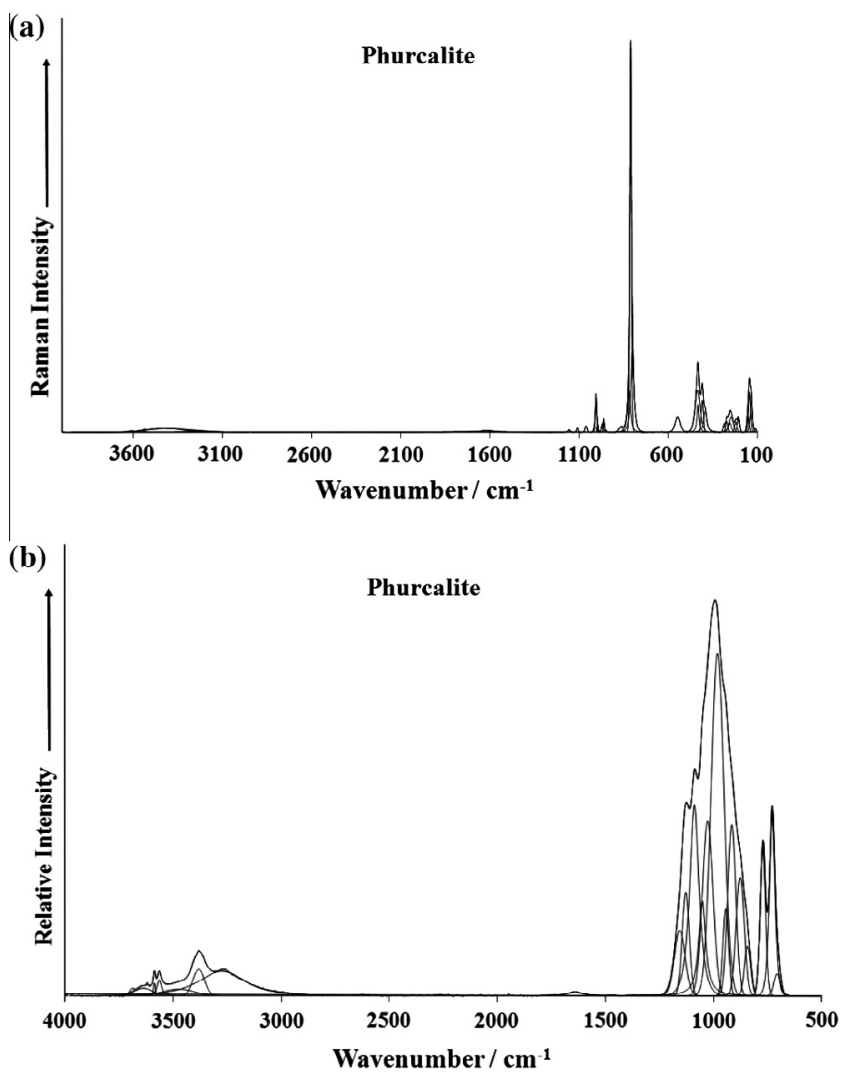

Fig. 3. (a) Raman spectrum of phurcalite (upper spectrum) over the $100-4000 \mathrm{~cm}^{-1}$ spectral range and (b) infrared spectrum of phurcalite (lower spectrum) over the $500-4000 \mathrm{~cm}^{-1}$ spectral range. (mean of 13 point analyses) - $\mathrm{CaO} 8.51, \mathrm{SiO}_{2} 0.36 \mathrm{P}_{2} \mathrm{O}_{5} 10.81, \mathrm{UO}_{3}$ $69.93, \mathrm{H}_{2} \mathrm{O}$ (calc.) 9.99 , total $99.60 \mathrm{wt}$. \% yield on the basis of $7 \mathrm{apfu}$ to empirical formulae $\mathrm{Ca}_{1.92}\left(\mathrm{UO}_{2}\right)_{3.09}\left[\left(\mathrm{PO}_{4}\right)_{1.92}\left(\mathrm{SiO}_{4}\right)_{0.08}\right]_{\Sigma 2.00}$ $\mathrm{O}_{1.97} .7 \mathrm{H}_{2} \mathrm{O}$. Minor content of $\mathrm{Al}$ (ED spectrum) was not confirmed by EPMA data, it probably represents only a heterogeneous contamination of sample surface.

\section{Raman and infrared spectroscopy}

From the Raman and infrared spectra of phurcalite may be inferred the presence of uranyl ions, $\left(\mathrm{UO}_{2}\right)^{2+}$, phosphate ions, $\left(\mathrm{PO}_{4}\right)^{3-}$, and hydrogen bonded water molecules in its crystal structure. A free uranyl, $\left(\mathrm{UO}_{2}\right)^{2+}$, point symmetry $D_{\propto h}$, should exhibit three fundamental modes: (a) symmetric stretching vibration $v_{1}$ $\left(\sum_{\mathrm{g}}^{+}\right)$, Raman active, approximately $900-750 \mathrm{~cm}^{-1}$, (b) doubly degenerate bending vibration $v_{2}(\delta)\left(\Pi_{\mathrm{u}}\right)$, infrared active, approximately $300-200 \mathrm{~cm}^{-1}$, and (c) antisymmetric stretching vibration $v_{3}\left(\Sigma_{\mathrm{u}}\right)$, infrared active, approximately $100-850 \mathrm{~cm}^{-1}$ [23]. Tetrahedral $T d$ symmetry is characteristic for phosphate, $\left(\mathrm{PO}_{4}\right)^{3-}$, anions. In the case of a free ion, there are nine normal vibrations characterised by four fundamental distinguishable modes of vibrations: (a) symmetric stretching vibration $v_{1}\left(A_{1}\right)$, Raman active, approximately $990-930 \mathrm{~cm}^{-1}$, (b) doubly degenerate in-plane bending vibration $v_{2}(\delta)(E)$, Raman active, approximately 490$410 \mathrm{~cm}^{-1}$, (c) triply degenerate antisymmetric stretching vibration $v_{3}\left(F_{2}\right)$, infrared and Raman active, approximately $1140-975 \mathrm{~cm}^{-1}$, and $(\mathrm{d})$ triply degenerate out-of-plane bending vibration $v_{4}(\delta)\left(F_{2}\right)$, infrared and Raman active, approximately $670-510 \mathrm{~cm}^{-1}$ [23-28]. Molecular water, $\mathrm{H}_{2} \mathrm{O}$, (point symmetry $C_{2 \mathrm{v}}$ is characterised by three fundamentals, symmetric and antisymmetric $\mathrm{OH}$ stretching
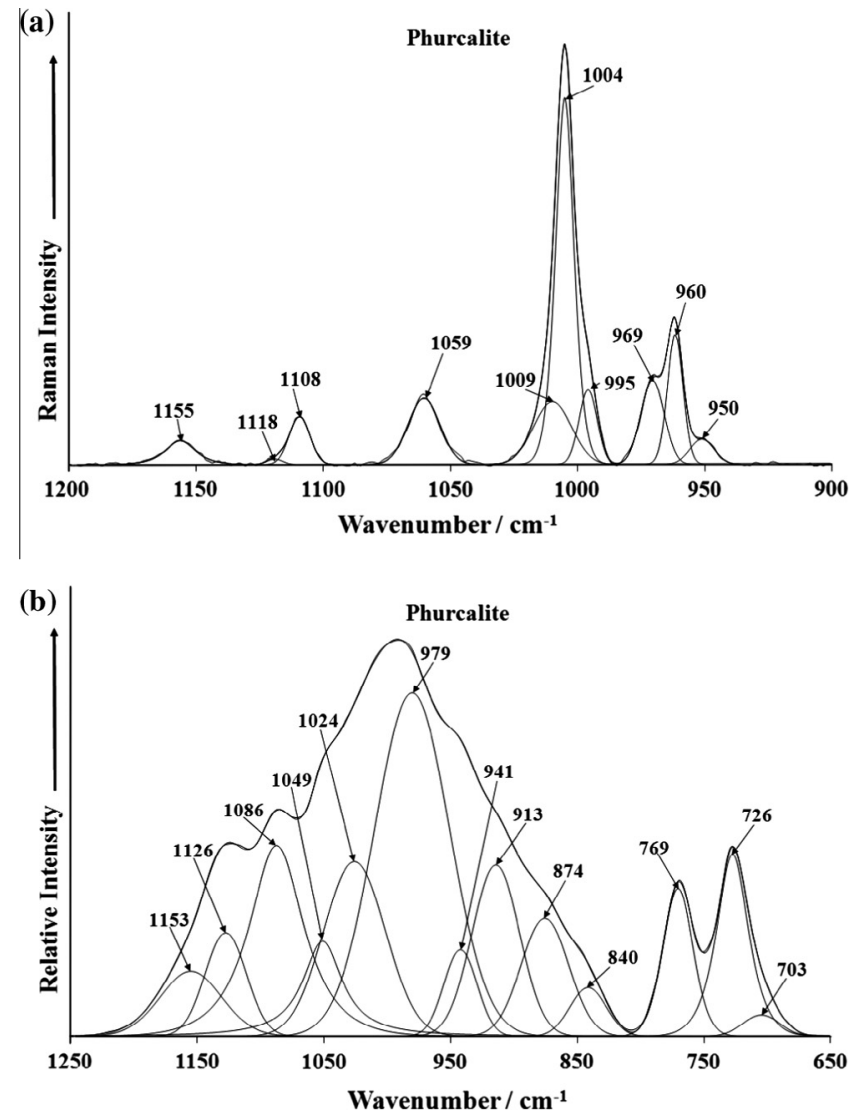

Fig. 4. (a) Raman spectrum of phurcalite (upper spectrum) in the $900-1200 \mathrm{~cm}^{-1}$ spectral range and (b) infrared spectrum of phurcalite (lower spectrum) in the 650$1250 \mathrm{~cm}^{-1}$ spectral range. 

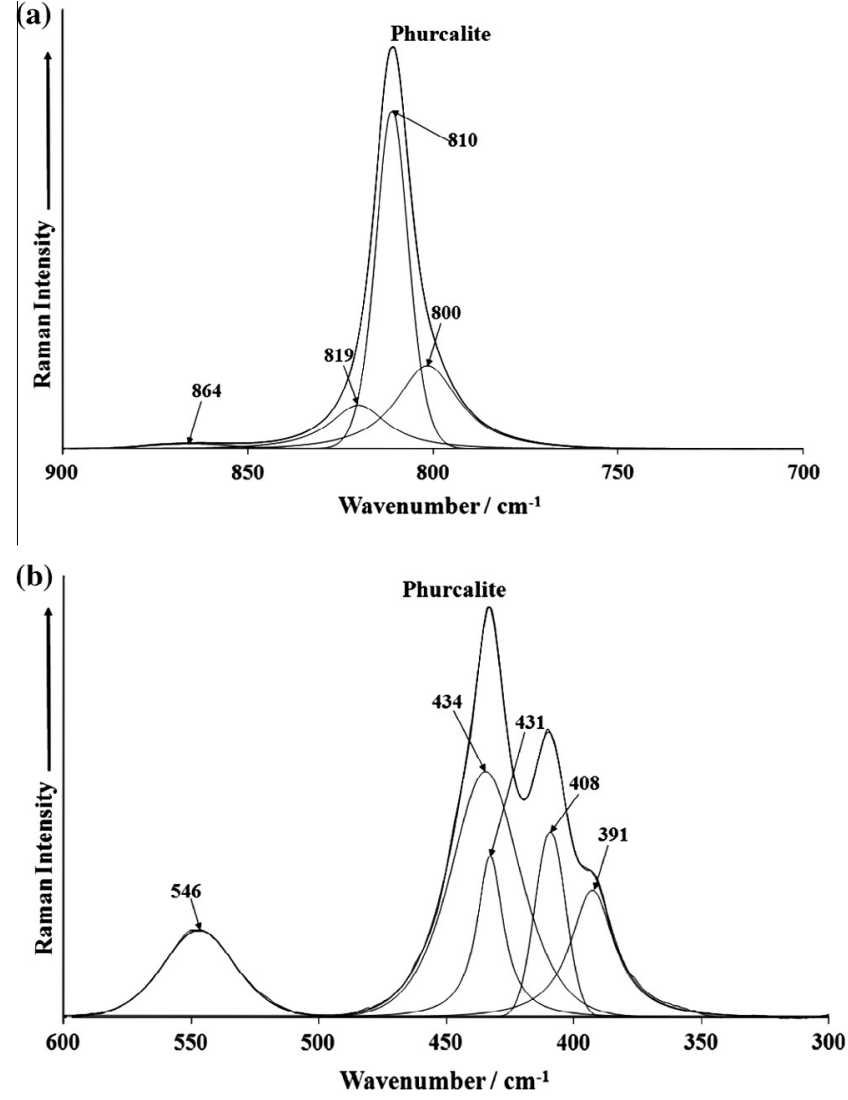

Fig. 5. (a) Raman spectrum of phurcalite (upper spectrum) in the $700-900 \mathrm{~cm}^{-1}$ spectral range and (b) Raman spectrum of phurcalite (lower spectrum) in the 300 $600 \mathrm{~cm}^{-1}$ spectral range.

vibrations $v_{1}\left(A_{1}\right)\left(\mathrm{H}_{2} \mathrm{O}(\mathrm{g}) 3656.65 \mathrm{~cm}^{-1}\right)$ and $v_{3}\left(B_{1}\right)\left(\mathrm{H}_{2} \mathrm{O}(\mathrm{g})\right.$ $3755.79 \mathrm{~cm}^{-1}$ ), both approximately $3600-2900 \mathrm{~cm}^{-1}$, and bending vibration $v_{2}\left(\delta \mathrm{H}_{2} \mathrm{O}\right)\left(A_{1}\right)$, approximately $1700-1590 \mathrm{~cm}^{-1}$. All vibrations are infrared and Raman active. In the range of approximately 900-300 $\mathrm{cm}^{-1}$, three types of libration modes can occur: $\tau$ twisting, $\omega$-wagging, and $\rho$-rocking $[23,25]$. Raman spectra of the phurcalite sample studied are presented in Figs. 3a (4000$\left.100 \mathrm{~cm}^{-1}\right)$, 4a $\left(1300-800 \mathrm{~cm}^{-1}\right)$, 5a $\left(800-300 \mathrm{~cm}^{-1}\right)$, 5b $(500-$ $\left.300 \mathrm{~cm}^{-1}\right)$, 6a $\left(3800-3000 \mathrm{~cm}^{-1}\right)$ and $7 \mathrm{a}\left(1800-1300 \mathrm{~cm}^{-1}\right)$, its infrared spectra in Figs. 3b $\left(4000-500 \mathrm{~cm}^{-1}\right)$, 4b (1300$\left.500 \mathrm{~cm}^{-1}\right), 6 \mathrm{~b}\left(3800-2600 \mathrm{~cm}^{-1}\right)$ and $7 \mathrm{~b}\left(1800-1300 \mathrm{~cm}^{-1}\right)$.

\section{Raman and infrared bands of uranyl, $\left(\mathrm{UO}_{2}\right)^{2+}$, units}

A Raman band at $810 \mathrm{~cm}^{-1}$ with two shoulders at 800 and $819 \mathrm{~cm}^{-1}$ is assigned to the $v_{1}\left(\mathrm{UO}_{2}\right)^{2+}$ symmetric stretching vibrations. Their number supports the X-ray single crystal structure analysis, from which was inferred that phurcalite contains three nonequivalent, structurally (symmetrically) different $\mathrm{U}^{6+}$ in its crystal structure. RRUFF samples R050534 and R060698 exhibit a Raman band approximately at $806 \mathrm{~cm}^{-1}$ with shoulders at 800 and $815 \mathrm{~cm}^{-1}$, and $810 \mathrm{~cm}^{-1}$, respectively. According to Bartlett and Cooney [26], U-O bond lengths in uranyl, $\left(\mathrm{UO}_{2}\right)^{2+}$, may be inferred from the wavenumbers assigned to the $v_{1}\left(\mathrm{UO}_{2}\right)^{2+}$. For $810 \mathrm{~cm}^{-1}$ (this paper), this calculated value is $1.80 \AA$, for RRUFF samples $\sim 809 \mathrm{~cm}^{-1}$ and $1.802 \AA$. These values are in excellent agreement with $\varnothing 1.805(1.81 ; 1.179 ; 1.815) \AA$ inferred from the $\mathrm{X}$-ray single crystal structure analysis [15]. Wavenumbers of Raman bands of the samples studied by Frost et al. [22] which may be attributed to the $v_{1}\left(\mathrm{UO}_{2}\right)^{2+}$ vary approximately from 796 to
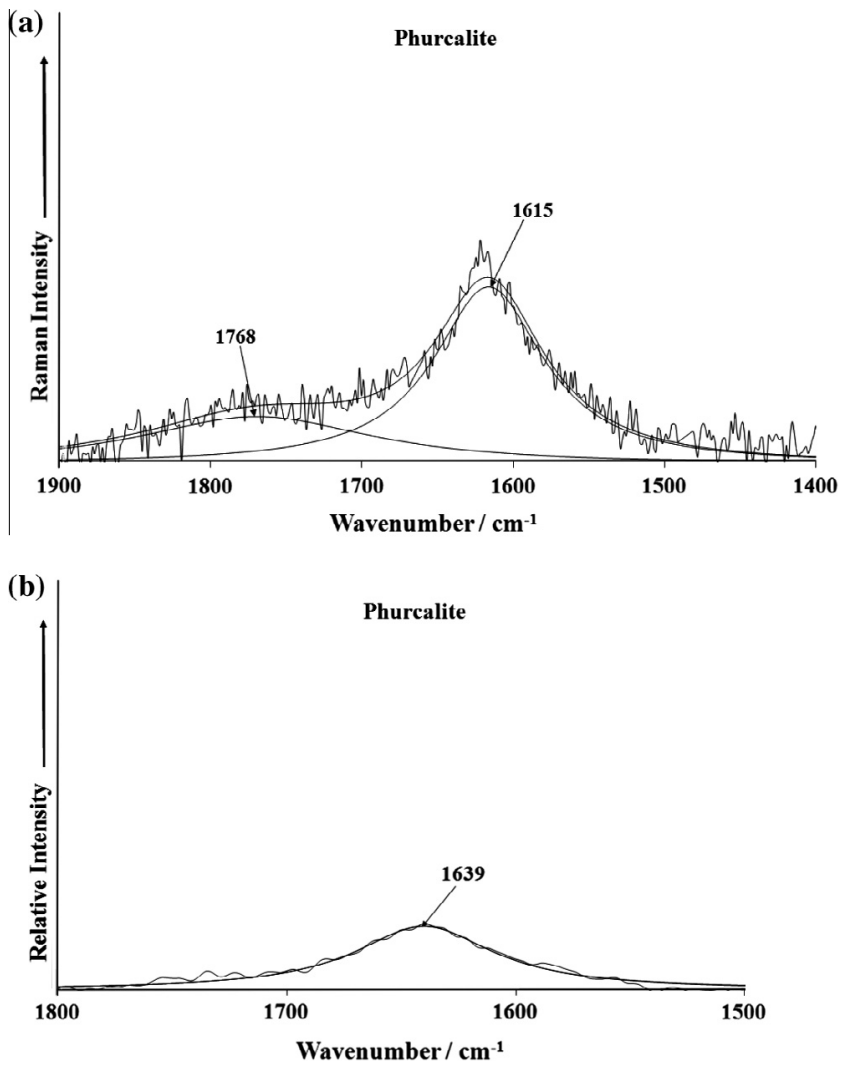

Fig. 6. (a) Raman spectrum of phurcalite (upper spectrum) in the $1400-1900 \mathrm{~cm}^{-1}$ spectral range and (b) infrared spectrum of phurcalite (lower spectrum) in the $1500-1800 \mathrm{~cm}^{-1}$ spectral range.

$811 \mathrm{~cm}^{-1}$, and therefore approximately from 1.81 to $1.80 \AA$ A. Wavenumbers of the infrared bands attributed to the $v_{3}\left(\mathrm{UO}_{2}\right)^{2+}$ antisymmetric stretching vibrations are $874 \mathrm{~cm}^{-1}$ (this paper), 893 or $884 \mathrm{~cm}^{-1}$ (two samples) [9], $890 \mathrm{~cm}^{-1}$ [18], $885 \mathrm{~cm}^{-1}$ [15] and approximately from 861 to $888 \mathrm{~cm}^{-1}$ [22]. Calculated values are $1.804,1.79,1.804,1.79,1.796,1.814$ to $1.793 \AA$, respectively, the average of them is $\sim 1.80 \AA$. Also all these calculated $\mathrm{U}-\mathrm{O}$ bond lengths in uranyl of the sample studied in this paper and those published are close to the lengths for three structurally nonequivalent uranyls given from the X-ray single crystal structure analysis of phurcalite by Atencio et al. [15]. Raman spectra below $300 \mathrm{~cm}^{-1}$ were not recorded. However, from the RRUFF data base and also [22] may be inferred that Raman bands related to the $v_{2}(\delta)$ bending vibrations are located close to $250 \mathrm{~cm}^{-1}$. Corresponding infrared band was observed at $255 \mathrm{~cm}^{-1}$ [15]. U-O bond lengths in uranyls, inferred from the wavenumbers of Raman and infrared bands assigned to uranyl stretching vibrations, are in agreement with the data presented by Burns $[2,27]$.

\section{Raman and infrared bands of phosphate, $\left(\mathrm{PO}_{4}\right)^{3-}$, units}

Raman bands at $1155,1118,1108,1059,1009,1004 \mathrm{~cm}^{-1}$ and infrared bands at 1153,1126, 1086, 1049 and $1024 \mathrm{~cm}^{-1}$ are assigned to the split triply degenerate $v_{3}\left(\mathrm{PO}_{4}\right)^{3-}$ antisymmetric stretching vibrations. Camargo [9] observed infrared bands at 1151, 1106, 1052 and 1000; 1136, 1098, $1042 \mathrm{~cm}^{-1}$ (two samples were studied), Brathwaite et al. [18] at 1148, 1110, 1063 and 1000; $1150,1105,1070 \mathrm{~cm}^{-1}$ (two samples were studied), Atencio et al. [15] two bands at 1140 and $1055 \mathrm{~cm}^{-1}$, and Frost et al. [22] infrared bands at 1148, 1110, 1080, 1052 and 1024, 1150, 1127, 1110, 

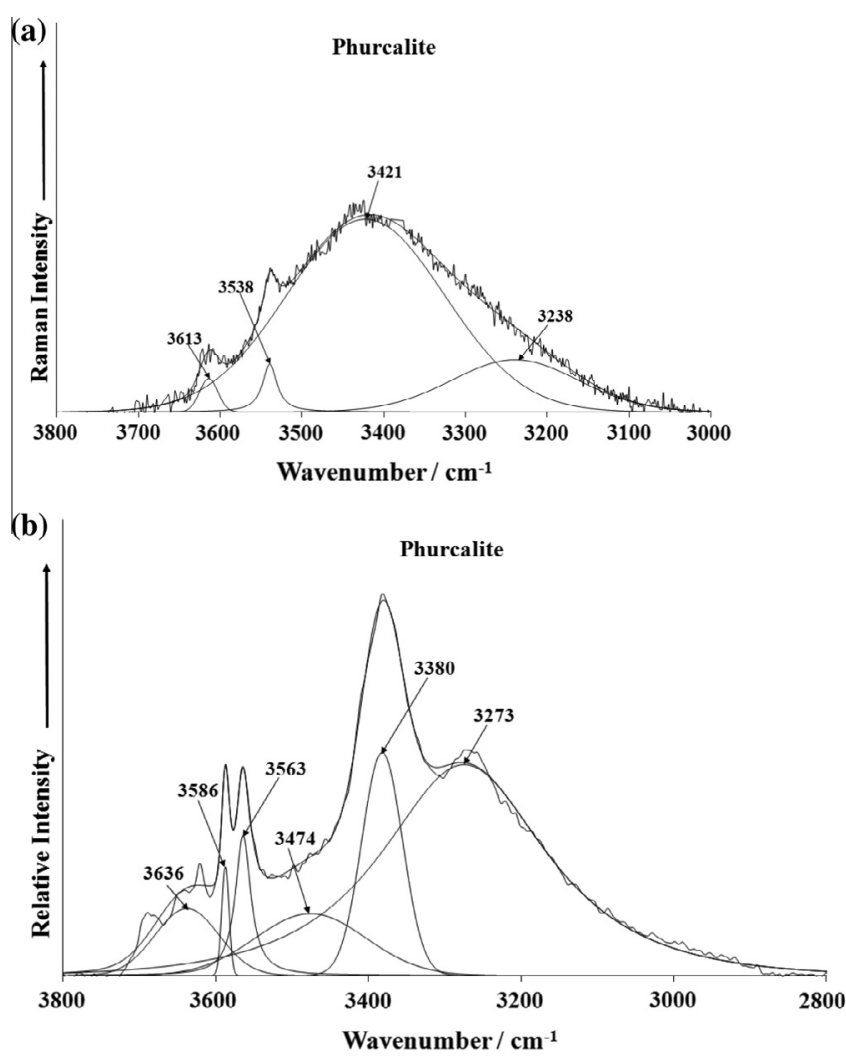

Fig. 7. (a) Raman spectrum of phurcalite (upper spectrum) in the $3000-3800 \mathrm{~cm}^{-1}$ spectral range and (b) infrared spectrum of phurcalite (lower spectrum) in the $2800-3800 \mathrm{~cm}^{-1}$ spectral range.

1062 and 1027; 1146, 1127, 1106, 1085, 1059 and $1029 \mathrm{~cm}^{-1}$ and Raman bands at 1105 and 1051; 1156, 1104, 1055 and 1007; 1151, and $1104 \mathrm{~cm}^{-1}$ (three samples were studied).

Raman bands at 995, 969, 960 and $950 \mathrm{~cm}^{-1}$ and infrared bands at 979 and $941 \mathrm{~cm}^{-1}$ are attributed to the $v_{1}\left(\mathrm{PO}_{4}\right)^{3-}$ symmetric stretching vibrations. Braithwaite et al. [18] observed infrared bands at 970 and $970 \mathrm{~cm}^{-1}$ (two samples studied), Atencio et al. [15] an infrared band at $960 \mathrm{~cm}^{-1}$, and Frost et al. [22] Raman bands at 997 and 956, 992, 967 and 958; 998 and $967 \mathrm{~cm}^{-1}$ (three samples studied).

The number of the observed bands proves the presence of structurally (symmetrically) nonequivalent phosphate units in the crystal structure of phurcalite. This is in agreement with the single crystal structure analysis of phurcalite.

A Raman band at $546 \mathrm{~cm}^{-1}$ and Raman bands at 434, 431, 408 and $391 \mathrm{~cm}^{-1}$ are assigned to the triply degenerate $v_{4}(\delta)\left(\mathrm{PO}_{4}\right)^{3-}$ out-of-plane bending vibration and to the doubly degenerate $v_{2}$ $(\delta)\left(\mathrm{PO}_{4}\right)^{3-}$ in plane bending vibrations, respectively. Braithwaite et al. [18] observed an infrared broad band at (590) $\mathrm{cm}^{-1}$ and another infrared band at $545 \mathrm{~cm}^{-1}$, in the second sample, only once band at $540 \mathrm{~cm}^{-1}$ was observed. Atencio et al. [15] described corresponding infrared bands at 575 and $540 \mathrm{~cm}^{-1}$ and 385 and $255 \mathrm{~cm}^{-1}$, respectively.

\section{Raman and infrared bands of molecular water vibrations}

Raman bands at 3613, 3538, 3421 and $3238 \mathrm{~cm}^{-1}$ and infrared bands at 3636, 3586, 3563, 3474, 3380 and $3238 \mathrm{~cm}^{-1}$ are assigned to the $v \mathrm{OH}$ stretching vibrations of structurally distinct and differ- ently hydrogen bonded water molecules. According to Libowitzky [28], O-H . . O hydrogen bond lengths approximately vary in the range from free or very weakly hydrogen bond hydrogen bonded water molecules $(>3.2 \AA$ ) to relatively strong hydrogen bonded water molecules $(\sim 2.72 \AA)$. Camargo studied to samples of his mineral X (in fact phurcalite) [9] and observed infrared bands at 3423 and $3335 \mathrm{~cm}^{-1}$, respectively, Braihwaite et al. [18] a broad band at $3400 \mathrm{~cm}^{-1}$ and a band at $3180 \mathrm{~cm}^{-1}$, Atentio et al. [15] a broad band at $3400 \mathrm{~cm}^{-1}$, Frost et al. [22] on studying three phurcalite samples up to twelve infrared bands between 3700 and $2700 \mathrm{~cm}^{-1}$.

A Raman at $1615 \mathrm{~cm}^{-1}$ and a broad infrared band at $1639 \mathrm{~cm}^{-1}$ are assigned to the $v_{2}(\delta) \mathrm{H}_{2} \mathrm{O}$ bending vibrations. These values correspond with infrared bands at 1612 or $1585 \mathrm{~cm}^{-1}$ [9], a broad infrared band at $1625 \mathrm{~cm}^{-1}$ [18], an infrared band at $1615 \mathrm{~cm}^{-1}$ [15], and three infrared bands approximately in the range from 1678 to $1594 \mathrm{~cm}^{-1}$ observed in three samples studied by Frost et al. [22]. Infrared bands at 941, 913, 769, 726 and $703 \mathrm{~cm}^{-1}$ may probably be related to the libration modes of hydrogen bonded water molecules. Only Frost et al. [22] observed infrared bands in these regions.

\section{Conclusions}

(a) Raman and infrared spectra of phurcalite from Red Canyon, Utah, USA, were recorded and tentatively interpreted.

(b) Observed Raman and infrared bands were tentatively assigned to the stretching and bending vibrations of $\left(\mathrm{UO}_{2}\right)^{2+}$ and $\left(\mathrm{PO}_{2}\right)^{3-}$ units and water molecules.

(c) Approximate U-O bond lengths in uranyl were calculated from the wavenumbers of the $\left(\mathrm{UO}_{2}\right)^{2+}$ symmetric and antisymmetric stretching vibrations [26]. These values are in agreement with the data of the crystal structure analysis of phurcalite [15] and general data presented by Burns [2,27].

(d) Approximate $\mathrm{O}-\mathrm{H} \cdots \mathrm{O}$ hydrogen bond lengths of water molecules were inferred from the wavenumbers of the $v \mathrm{OH}$ stretching vibrations of water molecules [28].

(e) The presence of symmetrically nonequivalent $\left(\mathrm{UO}_{2}\right)^{2+}$ and $\left(\mathrm{PO}_{4}\right)^{3-}$ and water molecules in the crystal structure of phurcalite was inferred from the observed number of these structural units. This agrees with the data from X-ray single crystal structure analysis [15].

\section{Acknowledgements}

The financial and infra-structure support of the Queensland University of Technology, School of Chemistry, Physics and Mechanical Engineering is gratefully acknowledged. The Australian Research Council (ARC) is thanked for funding the instrumentation. The authors would like to acknowledge the Center of Microscopy at the Universidade Federal de Minas Gerais (http://www.microscopia.ufmg.br) for providing the equipment and technical support for experiments involving electron microscopy.

Further support was provided by long-term project DKRVO 2014/02 of the Ministry of Culture of the Czech Republic (National Museum 00023272) to J.Č. and J.S. The downloading of the Raman spectra of phurcalite from the RRUFF web site is acknowledged.

\section{References}

[1] J. Čejka, Z. Urbanec, Secondary Uranium Minerals, Academia Praha, 1990. pp. 94.

[2] P.C. Burns, Can. Min. 43 (2005) 1839-1894.

[3] S. Krivovichev, J. Plášil, Mineralogy and crystallography of uranium, in: P.C. Burns, G.E. Sigmon (Eds.), Uranium - Cradle to Grave, Short Course Series, vol. 
43, Mineralogical Association of Canada, Winnipeg, Manitoba, pp. 15-119.

[4] M. Schindler, F.C. Hawthorne, Can. Min. 46 (2008) 467-501.

[5] F.C. Hawthorne, M. Schindler, Zeit. Krist. 223 (2008) 41-68.

[6] A. Locock, Unpublished Private Communication 2007.

[7] M. Deliens, P. Piret, Bull. Min. 101 (1978) 356-358;

M. Deliens, G. Comblain, Bull. Soc. Belge Géol. 87 (1978) 225-226.

[8] P. Piret, J.-P. Declerq, Acta Cryst. B34 (1978) 1677-1679.

[9] W.G.R. de Camargo, Boletim IGA (2) (1971) 85-201.

[10] J. Lencastre, M.M. Vairinho, Presidência do Conselho, Junta de Energia Nuclear, Lisboa, Portugal, 1970.

[11] R.T. Chew III, California Geol. 35 (1982) 246-247.

[12] H.E. Pemberton, Minerals of California, Mineralogical Abstracts $83 \mathrm{M} / 2483$ and $85 / 1182$.

[13] D. Atencio, R. Hypolito, Rev. Bras. Geo. 24 (1994) 43-51.

[14] D. Atencio, R. Neumann, J. Aldo Carmo Jr., E.H. Mishima, Rev. Bras.Geo. 20 (1990) 330.

[15] D. Atencio, R. Neumann, A.J.G.C. Silva, Y.P. Mascarenhas, Can. Min. 29 (1991) 95-105.
[16] K. Walenta, Der Erzgräber 7 (1993) 1-3.

[17] K. Walenta, Lapis 21 (1996) 75.

[18] R.S.W. Braithwaite, W.H. Paar, J.E. Chisholm, Min. Mag. 53 (1989) 583-589.

[19] Y. Singh, K.D.P. Singh, A.K. Bhatt, J. Geol. Soc. Ind. 53 (1999) 355-357.

[20] A.J.G.C. Silva, Thesis, Universidade de São Paulo 1990.

[21] D. Atencio, Thesis, Universidade de São Paulo 1991.

[22] R.L. Frost, M.L. Weier, W.N. Martens, J. Čejka, Vib. Spectrosc. 41 (2006) 205212.

[23] J. Čejka, Rev. Min. 38 (1999) 521-622.

[24] V.V. Pechkovskii, P.Ya Mel'nikova, E.D. Dzyuba, T.I. Barannikova, M.V. Nikanovich, Atlas of infrared spectra of phosphates. Orthophosphates. Nauka Moscow, 1981, pp. 248 (in Russian).

[25] K. Nakamoto, Infrared and Raman Spectra of Inorganic and Coordination Compounds, J. Wiley and Sons, New York, 1986. pp. 484.

[26] J.R. Bartlett, R.P. Cooney, J. Mol. Struct. 193 (1989) 295-300.

[27] P.C. Burns, Rev. Min. 38 (1999) 23-90.

[28] E. Libowitzky, Monat. Chem. 130 (1999) 1047-1059. 